\title{
Effect of Substitution of Chicken Breast for Alaska Pollack on Physico-chemical Characteristics and Quality in Surimi-like Materials Contained Different Cryoprotectants
}

\author{
Sang Keun $\mathrm{Jin}^{1}$, Young Jun $\mathrm{Choi}^{2}$, and Sun Jin Hur* \\ ${ }^{l}$ Department of Animal Resources Technology, Gyeongnam National University of Science \& Technology, \\ Jinju 660-758, Korea \\ ${ }^{2}$ Division of Marine Bioscience, Gyeongsang National University, Tongyeong 650-160, Korea \\ Department of Applied Biochemistry, Konkuk University, Chungju 380-701, Korea
}

\begin{abstract}
Surimi-like samples were divided into four groups (C, surimi-like material made from Alaska Pollack with all cryoprotectant ingredients; T1, surimi-like material made from chicken breast with sugar and a sorbitol-free cryoprotectant; T2, surimi-like material made from chicken breast with a sugar-free cryoprotectant; T3, surimi-like material made from chicken breast with all cryoprotectant ingredients). Water and protein content were lower in Alaska Pollack surimi-like material (C) than those in chicken breast surimi-like material. Centrifuge loss and cooking loss were higher in $\mathrm{C}$ than those in chicken breast surimi-like material. Lipid oxidation (thiobarbituric acid reactive substances) was lower in T3 than others during storage. In a sensory evaluation, overall acceptability was significantly higher in $\mathrm{C}$ than those in other samples during storage. As a result, we found that the raw material composition (Alaska Pollack or chicken breast) had a large influence on the physico-chemical characteristics and quality of surimi-like materials, whereas cryoprotectant composition may have less influence on the physico-chemical characteristics and quality of surimi-like materials.
\end{abstract}

Key words: surimi-like material, physico-chemical characteristics, chicken breast, alaska pollack, cryoprotectant

\section{Introduction}

Application of the surimi-like material technology in the production of a surimi-like products from meats such as chicken, pork and beef could provide a new approach towards increasing its value and utilization. Thus, various studies conducted to develop a surimi-like product from chicken (Lesiów and Xiong, 2003; Nowsad et al., 2000) sheep (Antonomanolaki et al., 1999), beef and pork (Park et al. 1996), and beef heart (Wang and Xiong 1999). The application of the surimi technology in the production of a surimi base product from other meat such as chicken, pork and beef could provide a new approach towards increasing its value and utilization (Jin et al., 2009). In the mean time, during frozen storage of fish muscle,

\footnotetext{
*Corresponding author: Sun Jin Hur, Department of Applied Biochemistry, Konkuk University, Chungju 380-701, Korea. Tel: 82-43-840-3571, Fax: 82-43-856-3572, E-mail: hursj@kku. ac.kr
}

denaturation and/or aggregation of myofibrillar proteins cause a loss of functional properties (Shenouda, 1980). Niwa (1992) also reported that this process lead to protein aggregation, textual changes, and loss of gelling and water holding functionality in fish. Thus, the addition of cryoprotectants is required in order to retain its functional properties (MacDonald and Lanier, 1994) and to protect the functionality of fish surimi-like material protein during frozen storage. Various cryoprotectants, such as sucrose, sorbitol, and polyphosphates, have been blended with surimi (Okada, 1985). Usually, surimi-like material from muscles other than fish is expected to have similar properties to surimi from fish, however the properties of surimi-like material from other muscles with cryoprotectant are still not always similar as a surimi-like material made from fish. Therefore, the objective of this study was to investigate the effect of substitution of chicken breast for Alaska Pollack on physic-chemical characteristics of surimi-like materials contained different cryoprotectants during freezing storage. 


\section{Materials and Methods}

\section{Sample preparation}

The surimi-like material samples were divided into 4 groups $(\mathrm{C}$, surimi-like material made from Alaska Pollack with whole ingredient cryoprotectant; $\mathrm{T} 1$, made from chicken breast with sugar and sorbitol free cryoprotectant; T2, made from chicken breast with sugar free cryoprotectant; T3, made from chicken breast with whole ingredient cryoprotectant), and specific ingredient composition of the surimi-like material is presented in Table 1. Fresh chicken breast was purchased from a commercial meat market and Alaska Pollack was purchased from Hansung Co (Korea). The external fat tissue and skin was removed from the muscles and the lean muscle was diced into approximately $2 \mathrm{~cm}$ cubes, and ground through a 3 $\mathrm{mm}$ diameter orifice using a mincer. Minced samples were homogenized by Polytron homogenizer (T25-B, IKA Sdn. Bhd., Malaysia) with distilled water at 15,000 rpm for $30 \mathrm{sec}$. The slurry was filtered through a $1 \mathrm{~mm}$-mesh metal screen to remove connective tissues. The filtrate was centrifuged (two times) at 10,000 g for $25 \mathrm{~min}$ and the supernatant containing fat and water-soluble proteins was discarded. The resulting sediment was mixed with other ingredients and then stuffed into PVDC casings (Ø3 $\times 15 \mathrm{~cm}$ ) and cooked in a cooking chamber at $90^{\circ} \mathrm{C}$ for $40 \mathrm{~min}$. After cooking, the surimi-like material samples were stored at $-20^{\circ} \mathrm{C}$ for experiments.

\section{Chemical composition}

Moisture, crude protein, crude fat contents and ash were determined according to the method described by AOAC (1990). Moisture was determined by the oven drying method at $110^{\circ} \mathrm{C}$ for $24 \mathrm{~h}$; for cooked samples total water content was calculated as (100-(total protein + total lipid + total ash)). Total protein content was determined by the Kjeldhal method. Total lipids were evaluated by the Soxhlet method. Ash was determined as the remnant weight after calcination of a $2 \mathrm{~g}$ sample at $550^{\circ} \mathrm{C}$ for $4 \mathrm{~h}$.

\section{Collagen}

The collagen content was determined after $24 \mathrm{~h}$ hydrolysis of $300 \mathrm{mg}$ of samples with $25 \mathrm{~mL} 6 \mathrm{M} \mathrm{HCl}$ at $110^{\circ} \mathrm{C}$ using the modified method cited by Palka (1999). Hydrolysates were clarified with active carbon, neutralized with $10 \mathrm{M}$ and $1 \mathrm{M} \mathrm{NaOH}$, and diluted with distilled water to $250 \mathrm{~mL}$. Hydrolysate $(4 \mathrm{~mL})$ and $2 \mathrm{~mL}$ of chloramine $\mathrm{T}$ solution $(1.41 \mathrm{~g}$ chloramine $\mathrm{T}, 10 \mathrm{~mL}$ distilled water, $10 \mathrm{~mL} n$-propanol and $80 \mathrm{~mL}$ citric buffer at $\mathrm{pH}$ 6) were mixed in a test tube and left for $20 \mathrm{~min}$ at room temperature. Next, $2 \mathrm{~mL}$ of 4-dimethyl-aminobenzaldehyde ( $p$-DABA) solution (10 g $p$-DABA, $35 \mathrm{~mL}$ $\mathrm{HClO}_{4}-60 \%$ and $65 \mathrm{~mL}$ isopropanol) was added. The solutions were shaken and heated at $60^{\circ} \mathrm{C}$ for $20 \mathrm{~min}$. The samples were cooled for $5 \mathrm{~min}$ in tap water and the absorbance was measured at $558 \mathrm{~nm}$. The amount of hydroxyproline was determined from a standard curve. The collagen content was calculated from hydroxyproline content using the coefficient 7.25.

\section{pH}

$\mathrm{pH}$ was measured using a digital $\mathrm{pH}$ meter (Model 420A, Orion, USA). Five grams of sample were cut into small pieces to which $45 \mathrm{~mL}$ of distilled water was added and slurry was made using a blender and the $\mathrm{pH}$ was recorded.

\section{Centrifuge loss}

Five grams of samples were weighed into centrifugation tubes and centrifuged at $5^{\circ} \mathrm{C}$ at low speed $(1,000 \mathrm{~g}$ for $15 \mathrm{~min}$ ). The WHC was determined as liquid loss and expressed as percentage of weight of liquid release. WHC $\%=($ weight before centrifuge - weight after centrifuge $) /$ (weight before centrifuge) $\times 100$.

\section{Cooking loss}

The samples were placed in polyethylene bags and cooked in a $100^{\circ} \mathrm{C}$ water bath until an internal temperature of $75^{\circ} \mathrm{C}$ was achieved. Cooking loss was calculated from differences in the weight of uncooked and cooked samples, expressed as percentage of initial weight. Cook-

Table 1. Experimental design and composition (\%) of cryoprotectants and raw materials

\begin{tabular}{cccccc}
\hline \hline Treatments & Sugar & Sorbitol & Polyphosphate & Raw material & Total \\
\hline C & 4 & 5 & 0.3 & Alaska Pollack surimi 90.7 & 100 \\
T1 & 0 & 0 & 0.3 & Chicken breast surimi 99.7 & 100 \\
T2 & 0 & 5 & 0.3 & Chickent breast surimi 94.7 & 100 \\
T3 & 4 & 5 & 0.3 & Chicken breast surimi 90.7 & 100 \\
\hline
\end{tabular}


ing loss $\%=$ (weight before cooking - weight after cooking $) /($ weight before cooking $) \times 100$.

\section{Shear force}

Five cylindrical pieces $3.5 \mathrm{~cm}$ wide and $3 \mathrm{~cm}$ thick were tempered at $20^{\circ} \mathrm{C}$ prior to measuring. The samples were sheared once through the center using an Instron 3343 (US/MX50, A\&D Co., USA) equipped with a Warner Bratzler shearing device (100 mm/min crosshead speed).

\section{Gel strength}

The gel strength was determined according to the method described by Phatcharat et al. (2006). Gels were equilibrated and evaluated at room temperature. Five cylindrical pieces $3.5 \mathrm{~cm}$ wide and $3 \mathrm{~cm}$ thick were tempered at $20^{\circ} \mathrm{C}$ prior to measuring. Breaking force and deformation were measured using a texture analyzer (EZtest, Shimadzu, Japan) equipped with a cylindrical plunger (diameter $5 \mathrm{~mm}$, depression speed $66 \mathrm{~mm} \mathrm{~min}$ ).

\section{Color}

Color (CIE L*(lightness), a* (redness), b* (yellowness)) was measured by using a Minolta colorimeter (CR400, Japan), with measurements standardized with respect to the white calibration plate. Five readings were made from the surface of samples. Whiteness was determined using the following formula: $100-\left(\left(100-\mathrm{L}^{*}\right)^{2}+\right.$ $\left.a^{* 2} b^{* 2}\right)^{1 / 2}$ (Park, 1994).

\section{Myoglobin}

The myoglobin content was determined by direct spectrophotometric measurement as described by Chaijan et al. (2004). Two grams of chopped sample were weighed into a $50 \mathrm{~mL}$ polypropylene centrifuge tube and $20 \mathrm{~mL}$ of 40 $\mathrm{mM}$ phosphate buffer, $\mathrm{pH} 6.8$ were added. The mixture was homogenized at $13,500 \mathrm{rpm}$ for $10 \mathrm{~s}$, followed by centrifuging at $3000 \mathrm{~g}$ for $30 \mathrm{~min}$ at $4^{\circ} \mathrm{C}$. The supernatant was filtered with Whatman No 1 filter paper. The supernatant was added with $0.2 \mathrm{~mL}$ of $1 \%$ (w/v) sodium dithionite to reduce the myoglobin. The myoglobin content was determined by direct spectrophotometric measurement at $555 \mathrm{~nm}$. Myoglobin content was calculated from the millimolar extinction coefficient of 7.6 and a molecular weight of 16,111 (Gomez-Basauri and Regenstein, 1992). The myoglobin content was expressed as $\mathrm{mg} / \mathrm{g}$ sample.

\section{TBARS (thiobarbituric acid reactive substances)}

Five grams of samples were weighed into a $50-\mathrm{mL}$ test tube and homogenized with $15 \mathrm{~mL}$ of deionized distilled water using the polytron homogenizer for $10 \mathrm{~s}$ at the highest speed. One $\mathrm{mL}$ of sample homogenate was transferred to a disposable test tube $(13 \times 100 \mathrm{~mm})$, and butylated hydroxyanisole $(50 \mu \mathrm{L}, 10 \%)$ and thiobarbituric acid/trichloroacetic acid (TBA/TCA) $(2 \mathrm{~mL})$ were added. The mixture was vortexed and then incubated in a boiling water bath for $15 \mathrm{~min}$ to develop color. The sample was cooled in a cold water for $10 \mathrm{~min}$, vortexed again, and centrifuged for $15 \mathrm{~min}$ at 2,000 g. The absorbance of the resulting supernatant solution was determined at $531 \mathrm{~nm}$ against a blank containing $1 \mathrm{~mL}$ of deionized distilled water and $2 \mathrm{~mL}$ of TBA/TCA solution. The amounts of TBARS were expressed as milligrams of malondialdehyde per kilogram of sample.

\section{Sensory evaluation}

Sensory evaluation was performed by a panel of 15 semi-trained tasters. Semi-trained taster is a potential consumer, and in the final analysis, the judgement of quality depends on the individual purchaser (Ruiz-Capillas et al., 2003). The panel evaluated each treatment within each replication in triplicate, and the evaluation was performed with the samples at room temperature. Triplicate responses were taken to monitor the inherent texture variability associated with this sample. One slice, $1 \mathrm{~cm}$ thick and 1.8 $\mathrm{cm}$ in diameter, was cut into six pie-shaped wedges and presented to each panelist. The panelists chose 3 of the most characteristic wedges in order to avoid a sample containing large pieces of connective tissue. The appearance, color, aroma, flavor, juiciness, tenderness and overall acceptability were evaluated using 9-point scale.

\section{Statistical analysis}

The data was analyzed using SAS software (SAS Inst. Inc., Cary, NC) by the Duncan's multiple range test to compare the differences among means. Significance was defined at $p<0.05$.

\section{Results and Discussion}

\section{Chemical composition}

Chemical composition is presented in Table 2. Water and ash content were higher in Alaska Pollack surimi-like material $(\mathrm{C})$ than chicken breast surimi-like material samples. No significant difference in collagen contents were found among the surimi-like material samples. The chemical compositions play an important role in surimi-like material quality. Luo et al. (2004) reported that the protein concentration greatly affected the gel properties of 
Table 2. Effect of substitution of chicken breast for Alaska Pollack on proximate composition in surimi contained different cryoprotectants

\begin{tabular}{lcccc}
\hline \hline \multirow{2}{*}{ Items } & \multicolumn{3}{c}{ Treatments $^{*}$} \\
\cline { 2 - 5 } & $\mathrm{C}$ & $\mathrm{T} 1$ & $\mathrm{~T} 2$ & $\mathrm{~T} 3$ \\
\hline Water (\%) & $78.73 \pm 0.27^{\mathrm{A}^{\dagger}}$ & $76.85 \pm 1.57^{\mathrm{B}}$ & $76.93 \pm 0.51^{\mathrm{B}}$ & $77.58 \pm 0.13^{\mathrm{AB}}$ \\
Protein (\%) & $17.99 \pm 0.37^{\mathrm{B}}$ & $19.77 \pm 0.32^{\mathrm{A}}$ & $18.94 \pm 0.37^{\mathrm{AB}}$ & $18.51 \pm 0.25^{\mathrm{B}}$ \\
Fat (\%) & $2.63 \pm 0.33^{\mathrm{B}}$ & $3.20 \pm 1.32^{\mathrm{B}}$ & $4.00 \pm 0.24^{\mathrm{A}}$ & $3.71 \pm 0.21^{\mathrm{AB}}$ \\
Ash (\%) & $0.66 \pm 0.01^{\mathrm{A}}$ & $0.17 \pm 0.06^{\mathrm{B}}$ & $0.12 \pm 0.04^{\mathrm{B}}$ & $0.20 \pm 0.04^{\mathrm{B}}$ \\
Collagen (mg/g) & $1.82 \pm 0.24^{1)}$ & $2.28 \pm 0.79$ & $1.49 \pm 0.35$ & $1.70 \pm 0.03$ \\
\hline
\end{tabular}

${ }^{*}$ Treatments are the same as in Table 1.

${ }^{\mathrm{A}-\mathrm{C}} \mathrm{Means} \pm \mathrm{SD}$ with different superscripts in the same row significantly differ at $p<0.05$.

${ }^{1)}$ Control of collagen (C) data was obtained from Jin et al. (2007).

Alaska Pollack and common carp surimi. The lipids in surimi-like material products may bring about an adverse effect on the surimi-like material quality, because the oxidized lipids interact with proteins, causing denaturation, polymerization and changes in functional properties (Smith, 1987). The water content is also a critical factor in surimi products (Uddin et al. 2006). In general, high protein, high myofibrillar, low crude fat and adequate water are required to make a high quality surimi-like material. In the present study, protein contents were significantly higher in chicken breast surimi-like material samples (T1 and T2) than Alaska Pollack surimi-like material (C). These differences may be due to raw material contents being higher in $\mathrm{T} 1$ and $\mathrm{T} 2$. These differences of water and protein contents may influence by the raw material contents, whereas cryoprotectant composition may have less influence on the chemical composition.

\section{Physico-chemical characteristics}

The physico-chemical characteristics results are presented in Table 3. $\mathrm{pH}$ was higher in $\mathrm{C}$ sample than chicken breast surimi-like material samples during all storage periods, whereas $\mathrm{T} 3$ was lower in $\mathrm{pH}$ during all storage periods compared with other surimi-like material samples. Centrifuge loss was higher in $\mathrm{C}$ sample compared with chicken breast surimi-like material samples, however, cooking loss was also higher in $\mathrm{C}$ sample than chicken breast surimi-like material samples during all storage periods. TBARS was higher in $\mathrm{C}$, whereas $\mathrm{T} 3 \mathrm{had}$ a lower TBARS value than other surimi-like material samples during all storage periods. Honikel (1987) reported that $\mathrm{pH}$ has a profound effect on the physical properties such as water holding capacity (WHC), tenderness and color in meat. Usually, high $\mathrm{pH}$, high protein content and low water content are closely related to the high WHC and shear force in meats. In the present study, an increase of $\mathrm{pH}$ may cause an increase of centrifuge loss in C samples. $\mathrm{pH}$ and centrifuge loss were significantly decreased with storage periods in all surimi-like material sample, whereas centrifuge loss of T2 (made from chicken breast with sugar free cryoprotectant) was not significantly different during storage period. These results indicate the composition of cryoprotectant may influence $\mathrm{pH}$ and centrifuge loss in chicken breast surimi-like material samples only. However, cooking loss was increased with storage periods in Alaska Pollack surimi-like material sample (C). As a result of this study, we assumed that many factors may influence the physico-chemical properties in surimilike material samples. Thus, further studies are needed to confirm these results. On the other hand, TBARS was significantly higher in $\mathrm{C}$ sample than chicken breast surimilike material samples. This may be due to $\mathrm{C}$ sample containing more polyunsaturated fatty acid than other samples, because polyunsaturated fatty acids are more susceptible to oxidation than monounsaturated and saturated fatty acids. Ahn et al.(1993) reported that the differences in fat content, fatty acid composition and the classes of lipids have significant effects on lipid oxidation only when oxygen has free access to the stored meat products. However, fat content was not significantly higher in $\mathrm{C}$ sample, thus, TBARS value may be less influenced by fat content, and more influenced by fatty acids. When comparing TBARS values among the chicken surimi-like material samples, lower TBARS value was found in T3. This may be due to T3 sample contained whole ingredient of cryoprotectant. Sugar, sorbitol and polyphosphate might be prevented lipid oxidation during storage periods.

\section{Shear force and gel strength}

The shear force and gel strength results are present in 
Table 3. Effect of substitution of chicken breast for Alaska Pollack on physico-chemical characteristics and TBARS in surimi contained different cryoprotectants

\begin{tabular}{|c|c|c|c|c|}
\hline \multirow{2}{*}{ Items } & \multirow{2}{*}{ Treatments ${ }^{*}$} & \multicolumn{3}{|c|}{ Storage periods (months) } \\
\hline & & 0 & 1.5 & 3 \\
\hline \multirow{4}{*}{$\mathrm{pH}^{1)}$} & $\mathrm{C}^{1)}$ & $7.20 \pm 0.03^{\mathrm{Aa} \dagger}$ & $6.30 \pm 0.10^{\mathrm{Ab}}$ & $6.21 \pm 0.05^{\mathrm{Ab}}$ \\
\hline & $\mathrm{T} 1$ & $6.47 \pm 0.02^{\mathrm{Ba}}$ & $5.89 \pm 0.22^{\mathrm{Bb}}$ & $5.88 \pm 0.37^{\mathrm{ABb}}$ \\
\hline & $\mathrm{T} 2$ & $6.40 \pm 0.01^{\mathrm{Ca}}$ & $5.85 \pm 0.22^{\mathrm{Bab}}$ & $5.70 \pm 0.52^{\mathrm{ABb}}$ \\
\hline & $\mathrm{T} 3$ & $6.31 \pm 0.02^{\mathrm{Da}}$ & $5.37 \pm 0.12^{\mathrm{Cb}}$ & $5.26 \pm 0.10^{\mathrm{Bb}}$ \\
\hline \multirow{4}{*}{$\begin{array}{c}\text { Centrifuge loss } \\
(\%)\end{array}$} & $\mathrm{C}^{1)}$ & $87.42 \pm 0.79^{\mathrm{Aa}}$ & $82.56 \pm 0.03^{\mathrm{Ab}}$ & $81.01 \pm 0.98^{\mathrm{Ac}}$ \\
\hline & $\mathrm{T} 1$ & $74.51 \pm 0.82^{\mathrm{Ca}}$ & $59.61 \pm 2.38^{\mathrm{Cb}}$ & $58.86 \pm 2.59^{\mathrm{Cb}}$ \\
\hline & $\mathrm{T} 2$ & $73.21 \pm 0.32^{\mathrm{C}}$ & $71.14 \pm 2.59^{\mathrm{B}}$ & $70.07 \pm 2.44^{\mathrm{B}}$ \\
\hline & $\mathrm{T} 3$ & $78.64 \pm 0.81^{\mathrm{Ba}}$ & $60.32 \pm 0.85^{\mathrm{Cb}}$ & $59.09 \pm 0.55^{\mathrm{Cb}}$ \\
\hline \multirow{4}{*}{ Cooking loss (\%) } & $\mathrm{C}^{1)}$ & $12.40 \pm 2.04^{\mathrm{Ab}}$ & $14.40 \pm 2.57^{\mathrm{Ab}}$ & $23.33 \pm 0.69^{\mathrm{Aa}}$ \\
\hline & $\mathrm{T} 1$ & $9.64 \pm 1.53^{\mathrm{A}}$ & $10.68 \pm 1.54^{\mathrm{AB}}$ & $9.77 \pm 0.70^{\mathrm{B}}$ \\
\hline & $\mathrm{T} 2$ & $6.49 \pm 1.27^{\mathrm{B}}$ & $6.92 \pm 0.69^{\mathrm{B}}$ & $5.41 \pm 1.97^{\mathrm{C}}$ \\
\hline & $\mathrm{T} 3$ & $11.26 \pm 1.47^{\mathrm{A}}$ & $12.16 \pm 2.94^{\mathrm{A}}$ & $9.16 \pm 1.13^{\mathrm{B}}$ \\
\hline \multirow{4}{*}{$\begin{array}{c}\text { TBARS } \\
\left(\mathrm{mgMA}^{\star} / \mathrm{kg}\right)\end{array}$} & $\mathrm{C}$ & $1.54 \pm 0.44^{\mathrm{A}}$ & $1.67 \pm 0.10^{\mathrm{A}}$ & $1.77 \pm 0.04^{\mathrm{A}}$ \\
\hline & $\mathrm{T} 1$ & $0.96 \pm 0.12^{\mathrm{B}}$ & $0.90 \pm 0.17^{\mathrm{C}}$ & $0.95 \pm 0.66^{\mathrm{AB}}$ \\
\hline & $\mathrm{T} 2$ & $0.64 \pm 0.09^{\mathrm{BCb}}$ & $1.35 \pm 0.06^{\mathrm{Ba}}$ & $1.44 \pm 0.07^{\mathrm{Aa}}$ \\
\hline & $\mathrm{T} 3$ & $0.44 \pm 0.02^{\mathrm{Cb}}$ & $0.49 \pm 0.08^{\mathrm{Dab}}$ & $0.65 \pm 0.12^{\mathrm{Ba}}$ \\
\hline
\end{tabular}

${ }^{*}$ Treatments are the same as in Table 1.

$\uparrow$ A-D Means \pm SD with different superscripts in the same column significantly differ at $p<0.05$.

${ }^{\mathrm{a}-\mathrm{c}}$ Means \pm SD with different superscripts in the same row significantly differ at $p<0.05$.

${ }^{*}$ Malondealdehyde. ${ }^{1)}$ Control (C) at 0 d data was obtained from Jin et al. (2007).

Table 4. Effect of substitution of chicken breast for Alaska Pollack on gel strength in surimi contained different cryoprotectants

\begin{tabular}{|c|c|c|c|c|}
\hline \multirow{2}{*}{ Items } & \multirow{2}{*}{ Treatments ${ }^{*}$} & \multicolumn{3}{|c|}{ Storage periods (mon) } \\
\hline & & 0 & 1.5 & 3 \\
\hline \multirow{4}{*}{$\begin{array}{l}\text { Shear force } \\
\left(\mathrm{kg} / \mathrm{cm}^{2}\right)\end{array}$} & $\mathrm{C}$ & $3.11 \pm 0.02^{\mathrm{C}^{\dagger}}$ & $3.07 \pm 0.10^{\mathrm{C}}$ & $3.06 \pm 0.17^{\mathrm{C}}$ \\
\hline & $\mathrm{T} 1$ & $6.81 \pm 0.07^{\mathrm{Ab}}$ & $7.03 \pm 0.09^{\mathrm{Aa}}$ & $6.88 \pm 0.03^{\mathrm{Ab}}$ \\
\hline & $\mathrm{T} 2$ & $6.94 \pm 0.09^{\mathrm{A}}$ & $7.04 \pm 0.09^{\mathrm{A}}$ & $6.87 \pm 0.17^{\mathrm{A}}$ \\
\hline & $\mathrm{T} 3$ & $4.34 \pm 0.17^{\mathrm{Bb}}$ & $4.92 \pm 0.22^{\mathrm{Ba}}$ & $4.88 \pm 0.21^{\mathrm{Ba}}$ \\
\hline \multirow{4}{*}{$\begin{array}{l}\text { Breaking force } \\
\text { (g) }\end{array}$} & $\mathrm{C}$ & $234.00 \pm 1.00^{\mathrm{A}}$ & $234.00 \pm 3.61^{\mathrm{A}}$ & $241.00 \pm 5.00^{\mathrm{A}}$ \\
\hline & $\mathrm{T} 1$ & $210.00 \pm 1.00^{\mathrm{B}}$ & $217.33 \pm 7.51^{\mathrm{B}}$ & $219.67 \pm 10.97^{\mathrm{B}}$ \\
\hline & $\mathrm{T} 2$ & $204.67 \pm 1.15^{\mathrm{Cb}}$ & $219.67 \pm 4.51^{\mathrm{Ba}}$ & $227.00 \pm 5.29^{\mathrm{AB}}$ \\
\hline & $\mathrm{T} 3$ & $206.33 \pm 1.15^{\mathrm{Cb}}$ & $221.67 \pm 4.93^{\mathrm{Ba}}$ & $228.33 \pm 7.23^{\mathrm{AB}}$ \\
\hline \multirow{4}{*}{$\begin{array}{l}\text { Deformation } \\
\quad(\mathrm{mm})\end{array}$} & $\mathrm{C}$ & $5.76 \pm 0.11^{\mathrm{Aa}}$ & $4.94 \pm 0.05^{\mathrm{b}}$ & $4.85 \pm 0.06^{\mathrm{b}}$ \\
\hline & $\mathrm{T} 1$ & $4.63 \pm 0.02^{\mathrm{Ba}}$ & $5.17 \pm 0.34^{\mathrm{a}}$ & $4.99 \pm 0.38^{\mathrm{a}}$ \\
\hline & $\mathrm{T} 2$ & $4.37 \pm 0.37^{\mathrm{Bb}}$ & $4.95 \pm 0.06^{\mathrm{a}}$ & $4.74 \pm 0.11^{\mathrm{ab}}$ \\
\hline & $\mathrm{T} 3$ & $4.60 \pm 0.02^{\mathrm{Bc}}$ & $4.97 \pm 0.01^{\mathrm{a}}$ & $4.72 \pm 0.09^{\mathrm{b}}$ \\
\hline
\end{tabular}

${ }^{*}$ Treatments are the same as in Table 1.

${ }^{\mathrm{A}-\mathrm{C}} \mathrm{Mean} s \pm \mathrm{SD}$ with different superscripts in the same column significantly differ at $p<0.05$.

${ }^{\mathrm{a}-\mathrm{b}}$ Means \pm SD with different superscripts in the same row significantly differ at $p<0.05$.

Table 4. Shear force value was significantly lower in C sample compared with chicken breast surimi-like material samples, whereas breaking force was higher in C sample than chicken breast surimi-like material samples during all storage periods. Deformation was higher in $\mathrm{C}$ sample than chicken breast surimi-like material samples at $0 \mathrm{~d}$ of 
storage. Thereafter, no significant difference was found in all samples. In the present study, shear force values were lower in $\mathrm{C}$ and $\mathrm{T} 3$ samples than other surimi-like material samples. This may be due to raw material (surimi) contents, because raw material contents were lower in $\mathrm{C}$ and T3 samples. However, cryoprotectant composition may be less influenced the shear force value.

\section{Color}

The color results are presented in Table 5. Lightness $\left(\mathrm{L}^{*}\right)$ and yellowness $\left(\mathrm{b}^{*}\right)$ were lower in $\mathrm{C}$ sample compared with chicken breast surimi-like material samples. Yellowness $\left(b^{*}\right)$ of $C$ sample was not significantly different during all storage periods, however, yellowness $\left(b^{*}\right)$ decreased after $15 \mathrm{~d}$ of storage in chicken breast surimilike material samples. Whiteness (W) was significantly higher in T3 sample than those of other samples at 0 day of storage and myoglobin content was not significantly dif- ferent among the samples during all storage periods. For surimi processing, myoglobin played an essential role in the whiteness (Chen, 2002), whiteness is one of the most important factors in quality of surimi. Ochiai et al. (2001) suggested that high-quality surimi with higher whiteness can be obtained when dark muscle is removed as much as possible. Thus, low myoglobin content is better than high myoglobin content for surimi-like material quality. In the present study, lightness $\left(\mathrm{L}^{*}\right)$ was higher in chicken breast surimi-like material samples but yellowness $\left(b^{*}\right)$ also higher in chicken breast samples, moreover no difference was found in myoglobin amount among the surimi-like material samples during all storage periods. Thus, myoglobin content may not influence the color of surimi-like material samples in the present study. As a result of this study, we found that the composition of cryoprotectant also does not have much influence on meat color because mechanical color was not significantly different (yellow-

Table 5. Effect of substitution of chicken breast for Alaska Pollack on color and myoglobin content in surimi contained different cryoprotectants

\begin{tabular}{|c|c|c|c|c|}
\hline \multirow{2}{*}{ Items } & \multirow{2}{*}{ Treatments* } & \multicolumn{3}{|c|}{ Storage periods (mon) } \\
\hline & & 0 & 1.5 & 3 \\
\hline \multirow{4}{*}{$\mathrm{L}^{*}$} & $C^{1)}$ & $55.93 \pm 1.28^{\mathrm{B}^{\dagger}}$ & $56.09 \pm 0.62^{\mathrm{B}}$ & $55.60 \pm 0.93^{\mathrm{B}}$ \\
\hline & $\mathrm{T} 1$ & $48.50 \pm 2.14^{\mathrm{Cb}}$ & $64.50 \pm 3.22^{\mathrm{Aa}}$ & $63.46 \pm 2.72^{\mathrm{Aa}}$ \\
\hline & $\mathrm{T} 2$ & $52.05 \pm 3.39^{\mathrm{BCb}}$ & $66.41 \pm 1.32^{\mathrm{Aa}}$ & $65.24 \pm 1.56^{\mathrm{Aa}}$ \\
\hline & $\mathrm{T} 3$ & $80.91 \pm 1.09^{\mathrm{Aa}}$ & $64.76 \pm 1.58^{\mathrm{Ab}}$ & $63.93 \pm 1.60^{\mathrm{Ab}}$ \\
\hline \multirow{4}{*}{$a^{*}$} & $\mathrm{C}^{1)}$ & $2.29 \pm 0.03^{\mathrm{Ca}}$ & $2.17 \pm 0.04^{\mathrm{Bb}}$ & $2.13 \pm 0.05^{\mathrm{Cb}}$ \\
\hline & $\mathrm{T} 1$ & $5.05 \pm 0.32^{\mathrm{B}}$ & $8.05 \pm 4.21^{\mathrm{AB}}$ & $4.71 \pm 0.34^{\mathrm{B}}$ \\
\hline & $\mathrm{T} 2$ & $4.97 \pm 0.20^{\mathrm{Bb}}$ & $10.40 \pm 4.48^{\mathrm{Aa}}$ & $11.76 \pm 0.44^{\mathrm{Aa}}$ \\
\hline & $\mathrm{T} 3$ & $7.00 \pm 0.23^{\mathrm{Aa}}$ & $5.21 \pm 0.41^{\mathrm{ABb}}$ & $5.10 \pm 0.55^{\mathrm{Bb}}$ \\
\hline \multirow{4}{*}{$b^{*}$} & $\mathrm{C}^{1)}$ & $1.09 \pm 0.15^{\mathrm{B}}$ & $1.15 \pm 0.06^{\mathrm{B}}$ & $1.15 \pm 0.04^{\mathrm{B}}$ \\
\hline & $\mathrm{T} 1$ & $6.37 \pm 0.95^{\mathrm{Aa}}$ & $4.41 \pm 0.70^{\mathrm{Ab}}$ & $4.31 \pm 0.61^{\mathrm{Ab}}$ \\
\hline & $\mathrm{T} 2$ & $6.74 \pm 1.09^{\mathrm{Aa}}$ & $4.73 \pm 0.21^{\mathrm{Ab}}$ & $4.61 \pm 0.11^{\mathrm{Ab}}$ \\
\hline & $\mathrm{T} 3$ & $7.52 \pm 0.44^{\mathrm{Aa}}$ & $3.99 \pm 0.50^{\mathrm{Ab}}$ & $4.03 \pm 0.61^{\mathrm{Ab}}$ \\
\hline \multirow{4}{*}{ W } & $\mathrm{C}^{1)}$ & $52.66 \pm 0.91^{\mathrm{B}}$ & $52.63 \pm 0.46$ & $52.16 \pm 0.84$ \\
\hline & $\mathrm{T} 1$ & $29.46 \pm 0.78^{\mathrm{Cb}}$ & $51.27 \pm 4.27^{\mathrm{a}}$ & $50.53 \pm 3.21^{\mathrm{a}}$ \\
\hline & $\mathrm{T} 2$ & $31.83 \pm 1.01^{\mathrm{Cb}}$ & $52.21 \pm 0.81^{\mathrm{a}}$ & $51.41 \pm 1.23^{\mathrm{a}}$ \\
\hline & $\mathrm{T} 3$ & $58.34 \pm 2.31^{\mathrm{Aa}}$ & $52.78 \pm 0.10^{\mathrm{b}}$ & $51.74 \pm 0.28^{\mathrm{b}}$ \\
\hline \multirow{4}{*}{ Myoglobin (mg/g) } & $\mathrm{C}^{1)}$ & $4.84 \pm 0.53^{\mathrm{b}}$ & $5.99 \pm 0.12^{\mathrm{a}}$ & $6.22 \pm 0.07^{\mathrm{a}}$ \\
\hline & $\mathrm{T} 1$ & $5.80 \pm 0.86$ & $6.14 \pm 1.46$ & $6.56 \pm 1.36$ \\
\hline & $\mathrm{T} 2$ & $7.10 \pm 1.03$ & $6.68 \pm 0.61$ & $6.99 \pm 0.18$ \\
\hline & $\mathrm{T} 3$ & $5.03 \pm 1.73$ & $5.41 \pm 1.21$ & $5.95 \pm 0.92$ \\
\hline
\end{tabular}

*Treatments are the same as in Table 1.

${ }^{\mathrm{A}-\mathrm{C}} \mathrm{M}$ Means $\pm \mathrm{SD}$ with different superscripts in the same column significantly differ at $p<0.05$.

${ }^{\mathrm{a}-\mathrm{b}}$ Means $\pm \mathrm{SD}$ with different superscripts in the same row significantly differ at $p<0.05$.

${ }^{1)} \mathrm{Control}(\mathrm{C})$ at 0 day data was obtained from Jin et al. (2007). 
ness) and no consistent trends (yellowness and whiteness) among the chicken breast surimi-like material samples were observed. However, color may be influenced by raw material contents.

\section{Sensory evaluation}

The sensory evaluation results are presented in Table 6 . In sensory evaluation, appearance and color were higher in $\mathrm{C}$ sample than other samples during all storage periods, whereas juiciness and tenderness was significantly lower in C sample than chicken breast surimi-like material samples. Overall acceptability was significantly higher in $\mathrm{C}$ sample compared with chicken breast surimi-like material samples during all storage periods. These findings indicate the color was higher in Alaska Pollack surimi-like material sample than chicken breast surimi-like material

Table 6. Effect of substitution of chicken breast for Alaska Pollack on sensory evaluation in surimi contained different cryoprotectants

\begin{tabular}{|c|c|c|c|c|}
\hline \multirow{2}{*}{ Items } & \multirow{2}{*}{ Treatments ${ }^{\dagger}$} & \multicolumn{3}{|c|}{ Storage periods (months) } \\
\hline & & 0 & 1.5 & 3 \\
\hline \multirow{4}{*}{ Appearance* } & $\mathrm{C}$ & $6.90 \pm 0.32^{\mathrm{A}}$ & $6.20 \pm 1.14^{\mathrm{A}}$ & $6.10 \pm 0.94^{\mathrm{A}}$ \\
\hline & $\mathrm{T} 1$ & $5.00 \pm 0.82^{\mathrm{B}}$ & $5.00 \pm 0.82^{\mathrm{B}}$ & $4.80 \pm 0.79^{\mathrm{B}}$ \\
\hline & $\mathrm{T} 2$ & $5.20 \pm 0.79^{\mathrm{B}}$ & $5.60 \pm 0.97^{\mathrm{AB}}$ & $5.20 \pm 0.79^{\mathrm{B}}$ \\
\hline & $\mathrm{T} 3$ & $5.60 \pm 0.97^{\mathrm{B}}$ & $5.00 \pm 0.94^{\mathrm{B}}$ & $4.80 \pm 0.79^{\mathrm{B}}$ \\
\hline \multirow{4}{*}{ Color } & $\mathrm{C}$ & $7.50 \pm 0.71^{\mathrm{Aa}}$ & $6.70 \pm 1.06^{\mathrm{Ab}}$ & $6.10 \pm 0.84^{\mathrm{Ab}}$ \\
\hline & $\mathrm{T} 1$ & $5.20 \pm 0.79^{\mathrm{C}}$ & $5.20 \pm 0.79^{\mathrm{B}}$ & $5.20 \pm 0.79^{\mathrm{B}}$ \\
\hline & $\mathrm{T} 2$ & $5.50 \pm 0.85^{\mathrm{BCab}}$ & $5.90 \pm 0.88^{\mathrm{ABa}}$ & $5.00 \pm 0.82^{\mathrm{Bb}}$ \\
\hline & $\mathrm{T} 3$ & $6.20 \pm 0.92^{\mathrm{Ba}}$ & $5.60 \pm 0.84^{\mathrm{Bab}}$ & $5.10 \pm 0.57^{\mathrm{Bb}}$ \\
\hline \multirow{4}{*}{ Aroma } & $\mathrm{C}$ & $5.70 \pm 0.95^{\mathrm{A}}$ & $5.50 \pm 1.27$ & $4.90 \pm 0.82$ \\
\hline & $\mathrm{T} 1$ & $4.40 \pm 0.52^{\mathrm{B}}$ & $5.30 \pm 1.70$ & $4.50 \pm 0.71$ \\
\hline & $\mathrm{T} 2$ & $4.50 \pm 0.71^{\mathrm{Bb}}$ & $5.60 \pm 0.52^{\mathrm{a}}$ & $5.20 \pm 0.79^{\mathrm{a}}$ \\
\hline & $\mathrm{T} 3$ & $4.50 \pm 0.71^{\mathrm{B}}$ & $5.00 \pm 0.82$ & $4.80 \pm 0.79$ \\
\hline \multirow{4}{*}{ Flavor } & $\mathrm{C}$ & $4.30 \pm 1.06$ & $4.30 \pm 1.06^{\mathrm{B}}$ & $4.20 \pm 0.97$ \\
\hline & $\mathrm{T} 1$ & $4.20 \pm 0.42$ & $4.80 \pm 1.03^{\mathrm{AB}}$ & $4.50 \pm 0.71$ \\
\hline & $\mathrm{T} 2$ & $4.50 \pm 0.53$ & $4.80 \pm 1.03^{\mathrm{AB}}$ & $4.60 \pm 0.70$ \\
\hline & $\mathrm{T} 3$ & $4.30 \pm 0.48^{\mathrm{b}}$ & $5.60 \pm 0.97^{\mathrm{Aa}}$ & $4.90 \pm 0.74^{b}$ \\
\hline \multirow{4}{*}{ Juiciness } & $\mathrm{C}$ & $3.90 \pm 0.57^{\mathrm{B}}$ & $4.50 \pm 1.08^{\mathrm{B}}$ & $4.20 \pm 1.14^{\mathrm{B}}$ \\
\hline & $\mathrm{T} 1$ & $5.60 \pm 0.70^{\mathrm{A}}$ & $5.60 \pm 0.70^{\mathrm{A}}$ & $5.00 \pm 0.94^{\mathrm{A}}$ \\
\hline & $\mathrm{T} 2$ & $5.50 \pm 0.53^{\mathrm{A}}$ & $5.60 \pm 0.52^{\mathrm{A}}$ & $5.40 \pm 0.52^{\mathrm{A}}$ \\
\hline & $\mathrm{T} 3$ & $5.40 \pm 0.52^{\mathrm{A}}$ & $5.20 \pm 1.14^{\mathrm{AB}}$ & $5.10 \pm 0.88^{\mathrm{A}}$ \\
\hline \multirow{4}{*}{ Tenderness } & $\mathrm{C}$ & $4.20 \pm 0.79^{\mathrm{B}}$ & $4.70 \pm 1.06^{\mathrm{B}}$ & $4.30 \pm 0.84^{\mathrm{B}}$ \\
\hline & $\mathrm{T} 1$ & $5.80 \pm 0.79^{\mathrm{A}}$ & $5.80 \pm 0.79^{\mathrm{A}}$ & $5.20 \pm 0.92^{\mathrm{A}}$ \\
\hline & $\mathrm{T} 2$ & $5.60 \pm 0.97^{\mathrm{A}}$ & $5.50 \pm 0.97^{\mathrm{AB}}$ & $4.80 \pm 0.92^{\mathrm{AB}}$ \\
\hline & $\mathrm{T} 3$ & $5.40 \pm 0.70^{\mathrm{A}}$ & $5.40 \pm 0.84^{\mathrm{AB}}$ & $5.00 \pm 0.82^{\mathrm{AB}}$ \\
\hline \multirow{4}{*}{$\begin{array}{c}\text { Overall } \\
\text { acceptability }\end{array}$} & $\mathrm{C}$ & $6.70 \pm 0.48^{\mathrm{Aa}}$ & $6.10 \pm 1.10^{\text {Aab }}$ & $5.90 \pm 0.92^{\mathrm{Ab}}$ \\
\hline & $\mathrm{T} 1$ & $5.20 \pm 0.79^{\mathrm{B}}$ & $5.20 \pm 0.79^{\mathrm{AB}}$ & $5.00 \pm 0.94^{\mathrm{B}}$ \\
\hline & $\mathrm{T} 2$ & $4.80 \pm 0.63^{\mathrm{B}}$ & $5.00 \pm 0.94^{\mathrm{B}}$ & $4.70 \pm 0.67^{\mathrm{B}}$ \\
\hline & $\mathrm{T} 3$ & $5.20 \pm 0.63^{\mathrm{Bab}}$ & $5.80 \pm 0.92^{\mathrm{ABa}}$ & $4.90 \pm 0.57^{\mathrm{Bb}}$ \\
\hline
\end{tabular}

*Appearance $(9=$ very good and $1=$ very bad), color $(9=$ very good and $1=$ very bad $)$, aroma $(9=$ very intense and $1=$ very weak \pm ), flavor $(9=$ very good and $1=$ very bad $)$, juiciness $(9=$ very juiciness and $1=$ very dry $)$, tenderness $(9=$ very tender and $1=$ very though), overall acceptability $(9=$ very good and $1=$ very bad $)$.

${ }^{\dagger}$ Treatments are the same as in Table 1.

$\$ \mathrm{~A}-\mathrm{C}$ Means $\pm \mathrm{SD}$ with different superscripts in the same row significantly differ at $p<0.05$.

${ }^{\mathrm{a}-\mathrm{b}}$ Means $\pm \mathrm{SD}$ with different superscripts in the same column significantly differ at $p<0.05$. 
samples although mechanical color showed no consistent trends among the samples, whereas tenderness was higher in chicken breast surimi-like material samples than Alaska Pollack surimi-like material sample. Sensory evaluation scores were not much different among the chicken breast surimi-like material samples. These results indicate the raw material contents and the composition of cryoprotectant may have less influence on the sensory evaluation score between chicken breast surimi-like material samples although other qualities were influenced by raw material contents and the composition of cryoprotectant. As a result of this study, we found that chicken breast surimi-like material samples were higher in protein, juiciness and tenderness compared with Alaska Pollack surimi-like material sample $(\mathrm{C})$, whereas $\mathrm{C}$ sample showed higher $\mathrm{pH}, \mathrm{WHC}$ and breaking force. Thus, we conclude that the raw materials composition (Alaska Pollack or chicken breast) may have large influence on the physicochemical characteristics and quality of surimi-like materials, whereas cryoprotectant compositions may have less influence on the physico-chemical characteristics and quality of surimi-like materials. Thus, further studies are needed for the improvement of surimi-like material made from chicken breast qualities.

\section{Acknowledgements}

This research was supported by Technology Development Program for ('Agriculture and Forestry' or 'Food' or 'Fisheries'), Ministry for Food, Agriculture, Forestry and Fisheries, Republic of Korea.

\section{References}

1. Ahn, D. U., Ajuyah, A., Wolfe, F. H., and Sim, J. S. (1993) Oxygen availability affects prooxidant catalyzed lipid oxidation of cooked turkey patties. J. Food Sci. 58, 278-291.

2. Antonomanolaki, R. E., Vareltzis, K. P., Georgakis, S. A., and Kaldrymidou, E. (1999) Thermal gelation properties of surimi-like material made from sheep meat. Meat Sci. 52, 429-435.

3. AOAC (1990) Official Methods of Analysis. 15th ed. Association of Official Analytical Chemists, Washington, DC, USA.

4. Chaijan, M., Benjakul, S., Visessanguan, W., and Faustman, C. (2004) Characteristics and gel properties of muscles from sardine (Sardinella gibbosa) and mackerel (Rastrelliger kanagurta) caught in Thailand. Food Res. Int. 37, 1021-1030.

5. Chen, H. H. (2002). Decoloration and gel-forming ability of horse mackerel mince by air-flotation washing. J. Food Sci. 67, 2970-2975.
6. Clark, Jr. J. M. and Switzer, R. L. (1977) Experimental biochemistry, W. H. Freemad \& Company, San Francisco, CA, USA.

7. Gomez-Basauri, J. V. and Regenstein, J. F. (1992) Vacuum packaging, ascorbic acid and frozen storage effect on heme and nonheme iron content of mackerel. J. Food Sci. 57, 1337-1339.

8. Honikel, K. O. (1987) The water binding of meat. Fleischwirtschaft, 67, 1098-1102.

9. Jin, S. K., Kim, I. S., Choi, Y. J., Kim, B. G., and Hur, S. J. (2009) The development of imitation crab stick containing chicken breast surimi. LWT-Food Sci. Tech. 42, 150-156.

10. Jin, S. K., Kim, I. S., Kim, S, J., Jeong, K, J., Lee, J. R., and Choi, Y. J. (2007) Effect of cryoprotectants on the physicochemical characteristics of chicken breast surimi manufactured by $\mathrm{pH}$ adjustment during freezing storage. Korean $J$. Food Sci. Ani. Resour. 27, 267-276.

11. Kuo, C. C. and Chu, C. Y. (2003) Quality characteristics of Chinese sausage made from PSE pork. Meat Sci. 64, 441449.

12. Lesiow, T. and Xiong, Y. L. (2003) Chicken muscle homogenate gelation properties: effect of $\mathrm{pH}$ and muscle fiber type. Meat Sci. 64, 399-403.

13. Luo, Y., Kuwahara, R., Kaneniwa, M., Murata, Y., and Yokoyama, M. (2004) Effect of soy protein isolate on gel properties of Alaska Pollack and common carp surimi at different setting conditions. J. Sci. Food Agr. 84, 663-671.

14. Macdonald, G. A. and Lanier, T. C. (1994) Actomyosin stabilization to freeze-thaw and heat denaturation by lactates salts. J. Food Sci. 59, 101-105.

15. Niwa, E. (1992) The chemistry of surimi gelation. In: Surimi Technology. Lanier, T. C. and Lee, C. M. (eds), Marcel Dekkar, Inc., NY, pp. 389-428.

16. Nowsad, A. A., Kanoh, S., and Niwa, E. (2000) Thermal gelation properties of spent hen mince and surimi. Poul. Sci. 79, 117-125.

17. Ochiai, Y., Ochiai, L., Hashimoto, K., and Watabe, S. (2001) Quantitative estimation of dark muscle content in the mackerel meat paste and its products using antisera against myosin light chains. J. Food Sci. 66, 1301-1305.

18. Okada, M. (1985) Ingredients on gel texture. In: Proceedings of the international symposium on engineered seafood including surimi. Martin, R. E. and Collette, R. L. (eds) National Fisheries Institute, Washington, DC.

19. Palka, K. (1999) Changes in intramuscular connective tissue and collagen solubility of bovine $\mathrm{m}$. semitendinosus during retorting. Meat Sci. 53, 189-194.

20. Park, J. W. (1994) Functional protein additives in surimi gels. J. Food Sci. 59, 525-527.

21. Park, S., Brewer, M. S., Novakofski, J., Bechtel, P. J., and Mckeith, F. K. (1996) Process and characteristics for a surimi-like material made from beef or pork. J. Food Sci. 61, 422-427.

22. Phatcharat, S., Benjakul, S., and Visessanguan, W. (2006) Effects of washing with oxidizing agents on the gel-forming ability and physicochemical properties of surimi produced 
from Bigeye snapper. Food Chem. 98, 431-439.

23. Ruiz-Capillas, C., Moral, A., and Villagacía. (2003). Use of semitrained panel members in the sensory evaluation of Hake (Merluccius Merluccius, L) analyzed statistically. $J$. Food Qual. 26, 181-195.

24. SAS (2001) SAS/STAT Software for Windows, SAS Institute Inc., Cary, NC, USA.

25. Shenouda, S. Y. K. (1980) Protein denaturation in frozen fish. Adv. Food Res. 26, 275-311.

26. Smith, D. M. (1987) Functional and biochemical changes in deboned turkey due to frozen storage and lipid oxidation. $J$.
Food Sci. 52, 22-27.

27. Uddin, M., Okazaki, E., Fukushima, H., Turza, S., Yumiko, Y., and Fukuda, Y. (2006) Nondestructive determination of water and protein in surimi by near-infrared spectroscopy. Food Chem. 96, 491-495.

28. Wang, B. and Xiong, Y. L. (1999) Characterization of the proteases involved in gel weakening of beef heart surimi. $J$. Agr. Food Chem. 47, 887-892.

(Received 2010.6.2/Revised 2011.1.18/Accepted 2011.4.7) 